\title{
INTENSITAS KERJA AKTIVITAS NELAYAN PADA PENGOPERASIAN SOMA PAJEKO (MINI PURSE SEINE) DI BITUNG
}

\section{WORK INTENSITY OF FISHERMEN ACTIVITY ON SOMA PAJEKO (MINI PURSE SEINE) OPERATION IN BITUNG}

\author{
Suci N Handayani ${ }^{1}$, Sugeng $\mathbf{H}$ Wisudo ${ }^{2}$, Budhi H Iskandar ${ }^{2}$, John Haluan ${ }^{3}$ \\ ${ }^{1}$ Program Studi Teknologi Perikanan Laut, Sekolah Pascasarjana \\ ${ }^{2}$ Departemen Pemanfaatan Sumberdaya Perikanan \\ ${ }^{3}$ Departemen Ilmu dan Teknologi Kelautan \\ Fakultas Perikanan dan Ilmu Kelautan, Institut Pertanian Bogor \\ Korespondensi : snh.dini@gmail.com
}

\begin{abstract}
There are factors of accident at sea in fishing activities which $80 \%$ caused by human errors (FAO 2009). The number of fishing vessel accidents within 7 years (January 2007-November 2013) in PPS Bitung occurred 40 times and tends to increase. There were accidents of six types of fishing vessels which majority soma pajeko (mini purse seine) that not recorded within 2010-2013 in Bitung. It is necessary to study fishermen safety on soma pajeko fishing operations because the number of fishermen is quite a lot. The research objectives are to identify and determine the work intensity of fishermen activity in soma pajeko operation which potentially cause work accident at sea. This research method is a numerical descriptive. Data were analyzed by identifying activities with Hierarchical Task. Analysis (HTA). Study result shows that stages of soma pajeko activities at PPS Bitung sorted into 8 phases with total 58 activities. Number of crew on soma pajeko fishing vessel examined as 28 persons with the greatest portion of responsibility burdens is Captain. Total work intensity to perform all activities (beginning to end) on soma pajeko operation requires crew involvement/ power forces equivalent to $563 \mathrm{OA}$ (men activity). The greatest primary work intensity is on the $5^{\text {th }}$ stage (bauling) which showed the biggest activity level with primary work intensity index of 0.29 . Involvement crew on bauling was the biggest intensity $(139 \mathrm{OA})$ which potentially occurs the risk possibility of work accidents caused by human error that bigger than other activities.
\end{abstract}

Keywords: Hierarchical Task Analysis, safety fishermen, soma pajeko, work intensity

\begin{abstract}
ABSTRAK
Faktor-faktor kecelakaan di laut dalam kegiatan penangkapan ikan sebanyak 80\% disebabkan oleh kesalahan manusia (FAO 2009). Jumlah kecelakaan kapal penangkap ikan dalam kurun waktu 7 tahun (Januari 2007-November 2013) di PPS Bitung terjadi 40 kali dan cenderung meningkat. Terdapat kecelakaan dari 6 jenis kapal penangkap ikan yang tidak tercatat tahun 2010-2013 di Bitung dengan mayoritas kapal soma pajeko (mini purse seine). Penting untuk mempelajari keselamatan nelayan pada operasi penangkapan ikan soma pajeko, karena jumlah nelayan yang terlibat cukup banyak. Tujuan penelitian ini adalah untuk mengidentifikasi aktivitas dan menentukan intensitas kerja dari aktivitas nelayan dalam operasi soma pajeko yang berpotensi menyebabkan kecelakaan kerja di laut. Metode penelitian ini adalah deskriptif numerik. Data dianalisis dengan mengidentifikasi aktivitas dengan Hierarchical Task Analysis (HTA). Hasil penelitian menunjukan bahwa tahapan kegiatan soma pajeko di PPS Bitung diurutkan menjadi 8 (delapan) tahap dengan jumlah 58 aktivitas. Jumlah awak kapal penangkap ikan soma pajeko sebanyak 28 orang dengan porsi tanggung jawab terbesar adalah kapten. Jumlah intensitas kerja untuk melakukan semua kegiatan (awal sampai akhir) pada pengoperasian soma pajeko memerlukan keterlibatan awak kapal dengan Intensitas Kerja Total (IKT) sebesar 563 OA (Orang Aktivitas). Tahap 5 (bauling) memiliki intensitas kerja terbesar yang menunjukkan tingkat aktivitas tertinggi dengan indeks Intensitas Kerja Primer (IKP) sebesar 0.29. Keterlibatan awak saat bauling merupakan intensitas kerja tertinggi (139 OA) sehingga berpotensi menimbulkan peluang resiko kecelakaan kerja yang disebabkan oleh kesalahan manusia lebih tinggi dibandingkan tahap kegiatan pengoperasian soma pajeko lainnya.
\end{abstract}

Kata kunci: Analisis Hierarki Proses, intensitas kerja, keselamatan nelayan, soma pajeko, 


\section{PENDAHULUAN}

Kegiatan perikanan tangkap penuh dengan tantangan serta dihadapkan pada resiko dan ketidakpastian. Salah satu bentuk resiko dan ketidakpastian tersebut adalah kecelakaan di laut. International Maritime Organization (IMO) tahun 2007 memaparkan bahwa kecelakaan (accident) adalah suatu kejadian yang tidak diinginkan yang melibatkan kematian, cedera, kehilangan atau kerusakaan kapal, kerugian harta benda atau kerusakan lingkungan. FAO (2009) mengatakan bahwa penyebab utama kecelakaan laut yang berujung pada hilangnya nyawa manusia ini adalah murni kesalahan manusia (human error). FAO (2010) memperkirakan bahwa sekitar 30 juta nelayan bekerja pada 4 juta kapal penangkap ikan yang beroperasi di dunia. Sekitar 98\% dari jumlah nelayan tersebut bekerja pada kapal dengan panjang kurang dari $24 \mathrm{~m}$, dimana untuk ukuran ini tidak tercakup di dalam peraturan Internasional. Jumlah kematian global diperkirakan oleh Organisasi Perburuhan Internasional (ILO 2007) pada tahun 1999 menjadi 24.000 kematian di seluruh dunia setiap tahun. FAO (2010) menambahkan penjelasan mengenai hal tersebut yakni tingkat kematian global tersebut akan lebih tinggi karena terdapat beberapa negara yang tidak memiliki data statistik atau informasi tingkat kematian global. Jumlah kecelakaan kapal penangkap ikan akan tercatat dalam kurun waktu 7 tahun (Januari 2007-November 2013) di Pelabuhan Perikanan Samudera (PSS) Bitung terjadi sebanyak 40 kali dan cenderung meningkat hingga bulan November 2013 (Gambar 1a). Kecelakaan terbesar mayoritas disebabkan oleh kerusakan mesin (57\%), tenggelam (18\%), tubrukan kapal (collision) (5\%) dan lainnya (Gambar 1b).

Gambar 2 (a) dan (b) masing-masing menggambarkan persentase kecelakaan kapal berdasarkan unit penangkapan dan jumlah awak kapal yang ada pada masingmasing unit penangkapan tersebut. Tiga kecelakaan paling banyak terjadi adalah pada jenis kapal tuna hand line (22\%), purse seine (13\%) dan perahu lampu (15\%). Persentase data kecelakaan kapal yang tidak tercatat jenis kapalnya (tda) sebanyak (20\%) selain itu masih ada kecelakaan yang tidak tercatat (tda) oleh Syahbandar Perikanan Bitung pada tahun 2010-2013 terjadi pada kapal ikan jenis pajeko (mini purse seine) sebanyak 6 kapal dan 1 kapal tuna longline. Berdasarkan jumlah ABK yang tercatat di dalam manifest laporan kecelakaan kapal Syahbandar Perikanan PPS Bitung, jumlah kecelakaan tersebut tidak menjelaskan bagaimana kondisi korban jiwa atau cedera awak kapal. Jumlah nelayan yang berpotensi menjadi korban kecelakaan terbesar adalah pada jenis kapal purse seine dengan jumlah korban 125 orang. FAO (2009) mengatakan bahwa penyebab utama kecelakaan laut yang berujung pada hilangnya nyawa manusia ini adalah murni kelalaian manusia (human erros). Otoritas yang berwenang harus menetapkan langkah-langkah yang akan dilakukan untuk memungkinkan kemudahan memperoleh informasi yang jelas saat berada di atas kapal agar nelayan dapat bekerja dengan nyaman sesuai dengan hak dan kewajibannya, seperti mengenai kondisi kerja yang ada (Purwangka et al. 2013). Berdasarkan permasalahan tersebut di atas maka perlu dilakukan penelitian terhadap keselamatan kerja nelayan pada aktivitas perikanan soma pajeko (mini purse seine), karena di dalam unit penangkapan ini jumlah nelayan yang terlibat cukup banyak. Tujuan dari penelitian ini adalah untuk mengidentifikasi aktivitas dan mengetahui intensitas kerja nelayan dalam pengoperasian soma pajeko yang berpotensi untuk menimbulkan terjadinya kecelakaan kerja di laut.

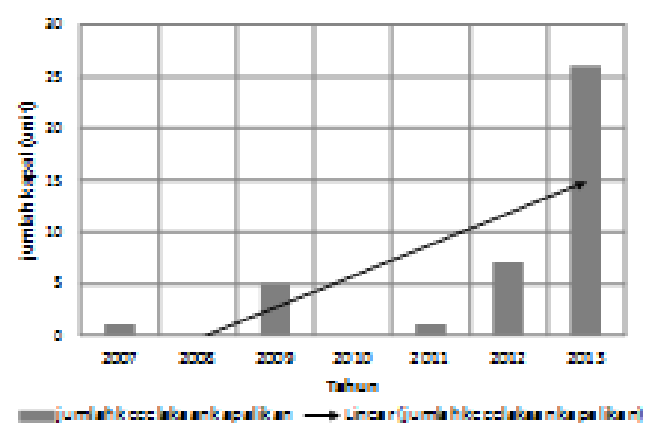

(a)

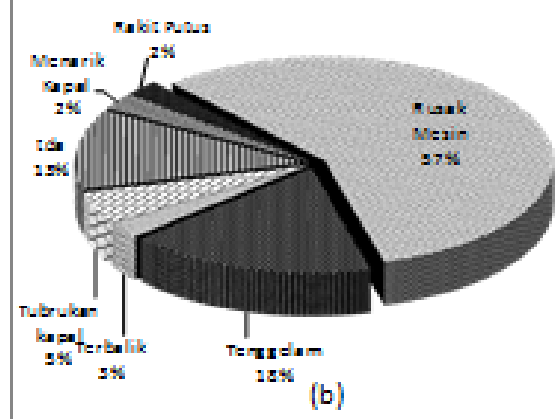

Gambar 1. Kecelakaan kapal penangkap ikan 2007-2010 dan penyebabnya 


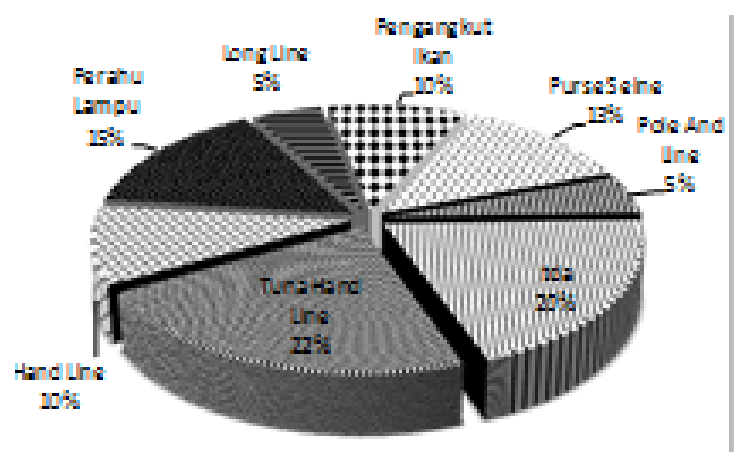

(a)

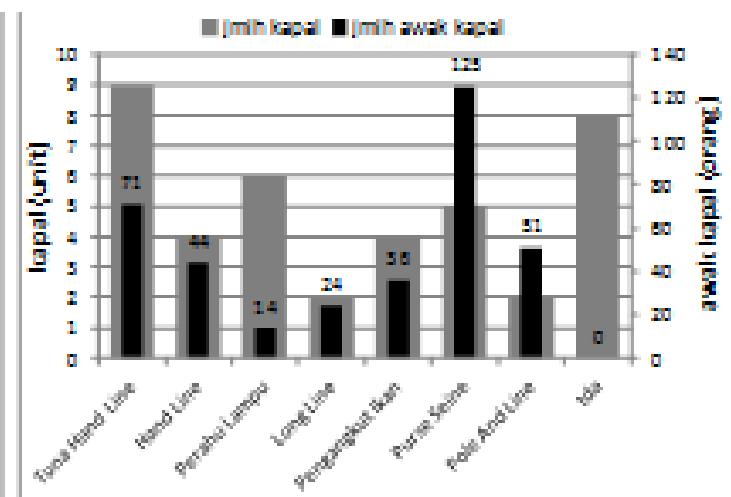

(b)

Gambar 2. Persentase kecelakaan kapal penangkap ikan dan jumlah awak kapal

\section{METODE PENELITIAN}

Penelitian dilakukan pada bulan November-Desember 2013. Lokasi penelitian dilakukan di Bitung, Sulawesi Utara.

Metode penelitian yang digunakan adalah observasi dan deskriptif kuantitatif. Metode observasi dilakukan secara langsung dengan mengikuti trip penangkapan soma pajeko. Observasi ini dilakukan terhadap unit penangkapan ikan soma pajeko yang beroperasi di Bitung Sulawesi Utara untuk melihat secara langsung aktivitas penangkapan ikan dengan unit soma pajeko. Metode deskriptif kuantitatif digunakan dalam menggambarkan aktivitas pengoperasian soma pajeko dari tahap awal hingga akhir dengan pendekatan kuantitatif untuk mendapatkan nilai dari setiap tahap aktivitas tersebut.

\section{Teknik pengumpulan data}

Data yang dikumpulkan meliputi data primer dan sekunder. Pengumpulan data primer menurut Sugiyono (2011) dapat dilakukan dengan teknik penentuan sampel dengan pertimbangan tertentu (purposive sampling). Jumlah data yang diteliti akan disesuaikan dengan kebutuhan penelitian. Hal ini dilakukan dengan pertimbangan jumlah narasumber (awak kapal) yang banyak dalam 1 unit soma pajeko. Unit Soma pajeko terbatas pada kriteria Perahu Motor Tempel (PMT) dengan panjang kurang dari 24 meter dengan pengoperasian one day fishing.

Data dan informasi yang berhubungan dengan aktivitas pengoperasian soma pajeko dapat ditelaah secara mendalam dengan pedoman wawancara yang telah disiapkan sebelumnya. Hal-hal yang digali dengan wawancara berhubungan dengan pekerja di atas kapal (nakhoda dan ABK), pekerjaan, dan lingkungan kerja pengoperasian unit penangkapan ikan soma pajeko. Data sekunder diperoleh dari penelusuran pustaka untuk digunakan sebagai penunjang data primer. Jenis dan sumber data yang dikumpulkan disampaikan pada Tabel 1.

Prosedur teknik pengumpulan data untuk gambaran aktivitas soma pajeko dilakukan dengan pengambilan gambar menggunakan alat ukur kamera video. Data kecelakaan kerja dan informasi lainnya yang mendukung dilakukan dengan wawancara mendalam berdasarkan pedoman wawancara yang sudah disiapkan sebelumnya. Data yang dikumpulkan diolah dengan pengelompokkan dan tabulasi sebelum dianalisis lebih lanjut. Data yang telah diolah selanjutnya akan dianalisis mengacu pada metode Formal Safety Assessment (FSA) dari IMO.

\section{Analisis data}

Aktivitas pengoperasian soma pajeko di Bitung

Tahap pertama dari metode ini adalah identifikasi aktivitas dengan metode HTA. Total aktivitas kerja dalam unit soma pajeko merupakan fungsi dari aktivitas primer dan sekunder yang dapat dirumuskan dengan fungsi sebagai berikut:

Total Aktivitas kerja $=\mathrm{f}$ (Aktivitas Primer, Aktivitas Sekunder)

sehingga dapat dijabarkan menjadi :

Total Aktivitas Kerja $=\sum_{i=1}^{n}$ Primer $_{i}+\sum_{i=1}^{n}$ Sekunder

dengan :

$i=$ tahap $\mathrm{ke}-1,2, \ldots . ., \mathrm{n}$ 
$n=$ jumlah tahap aktivitas

Intensitas kerja aktivitas nelayan pada pengoperasian soma pajeko

Work intensity (Intensitas Kerja) sebagian besar diteliti melalui studi kuantitatif dengan menggunakan instrumen survei skala besar dan telah dipahami sebagai serangkaian pengukuran seperti: kecepatan kerja (pace of work), kebutuhan untuk memenuhi tenggat waktu yang ketat, seberapa keras atau seberapa banyak usaha pekerja dimasukkan ke dalam pekerjaan mereka (Hamilton 2007).

Menurut Kamus Besar Bahasa Indonesia (KBBI) intensitas adalah keadaan tingkatan atau ukuran intensnya. Intensitas kerja yang merupakan ukuran jumlah awak kapal (orang) yang terlibat dalam 1 aktivitas. Satuan untuk intensitas kerja ini yang dipakai adalah Orang Aktivitas (OA). Intensitas kerja primer dan sekunder dihitung untuk mendapatkan nilai total intensitas kerja. Kedua intensitas tersebut dirumuskan sebagai berikut:

$\mathrm{IKP}=\sum_{i=1}^{n}(\mathrm{IKPi}+\ldots+I K P n) O A$
$\mathrm{IKS}=\sum_{i=1}^{n}(I K S i+\ldots+I K S n)$

$\mathrm{IKT}=(I K P+I K S) O A$

Indeks IKP tahap $k e-i=\frac{I P i}{I P}$

Persamaan diatas akan menghasilkan Intensitas Kerja Total (IKT). Indeks Intensitas Kerja Primer (IKP) digunakan dalam menentukan ranking. Nilai IKP masingmasing tahap aktivitas diurutkan dari nilai IKP terbesar hingga terkecil. Menurut Silaban (2010), terdapat hubungan yang sangat signifikan $(p<0.01)$ antara jumlah keterlibatan tenaga kerja dengan jumlah kecelakaan kerja. IKP yang paling besar menunjukkan ranking aktivitas paling tinggi dimana keterlibatan awak kapal paling besar. Pada aktivitas dimana keterlibatan awak kapal paling banyak akan memiliki peluang terjadinya risiko kecelakaan yang lebih tinggi dibandingkan aktivitas lainnya.

\section{HASIL DAN PEMBAHASAN}

Perikanan Soma pajeko termasuk ke dalam perikanan mini purse seine yang sampai saat ini masih banyak dioperasikan di perairan Bitung, Sulawesi Utara. Kapal penangkapan yang digunakan untuk

Tabel 1. Jenis dan Sumber Data Penelitian

Jenis data

Sumber data

1. Unit penangkapan soma pajeko

- Kapal, meliputi dimensi, tonase, kondisi mesin dan kelengkapan surat ijin

- Alat, meliputi dimensi kondisi alat, dan metode pengoperasian

- Nelayan, meliputi jumlah nelayan (termasuk nakhoda dan ABK), umur, pendidikan, Struktur organisasi di atas kapal

2. Urutan aktivitas pengoperasian soma pajeko

- Persiapan

- Loading

- Pelayaran dari fishing base menuju fishing ground

- Setting

- Hauling

- Penanganan hasil tangkapan di atas kapal

- Pelayaran dari fishing base menuju fishing ground

- Unloading

3. Perlengkapan alat keselamatan di Personal Protector Equipment, emergency signal, laut radio, alat keselamatan di kapal

4. Data informasi kecelakaan kerja Dokumen-dokumen yang mendukung soma pajeko di laut 
menangkap ikan pelagis kecil adalah kapal yang digunakan untuk mengoperasikan mini purse seine yang menurut istilah nelayan dari Bitung disebut soma pajeko. Umumnya ukuran kapal soma pajeko yang berasal dari Bitung mempunyai ukuran kapal panjang (LOA) 12-19 meter dengan personil kerja 1922 orang (Karman 2008). Berdasarkan data Syahbandar Perikanan 2009 panjang kapal (LOA) soma pajeko 11-14 meter dengan ABK 9-25 orang. Observasi dilakukan pada unit penangkapan ikan soma pajeko dengan dimensi panjang kapal (LOA=12 meter), lebar kapal $(B=3$ meter $)$, dalam $(D=1$ meter $)$ dengan total awak kapal (ABK dan Kapten) sebanyak 28 orang.

\section{Kondisi umum nelayan soma pajeko}

Perikanan soma pajeko tidak terlepas dari kapal yang memuat personil kerja (nelayan) dan hasil tangkapannya. Kondisi umum nelayan soma pajeko di PPS Bitung pada Gambar 3 menunjukkan tingkat pendidikan (a) dan pengalaman kerja nelayan (b). Tingkat pendidikan nelayan soma pajeko di PPS Bitung setara SMA/ SMK sebanyak $45 \%$. Menurut Suwardjo et al. (2010), untuk menguasai keahlian atau keterampilan sebagai seorang nakhoda kapal kecil maka seorang nakhoda kapal minimum berpendidikan menengah perikanan atau pendidikan SLTA umum ditambah pelatihan kepelautan meliputi pelayaran dan pengoperasian kapal, keselamatan dan penangkapan ikan. Sementara itu seluruh awak kapal (nakhoda dan ABK) kapal penangkap ikan diwajibkan memiliki kompetensi keselamatan yang diperoleh melalui Basic Safety Training (BST). Salah satu persyaratan peserta untuk mengikuti pelatihan BST harus lulusan SLTP.

Jumlah awak pada unit penangkapan ikan yang diteliti memiliki total awak kapal sebanyak 28 orang dengan pengalaman kerja kapten kapal selama 20 tahun dengan kompentensi SKK-60 Mil. Sebanyak $40 \%$ nelayan yang bekerja di perikanan soma pajeko mempunyai pengalaman 10-20 tahun. Berdasarkan 30 orang awak kapal yang terdaftar di 1 unit kapal soma pajeko hanya ada 2 orang yang pernah melakukan pelatihan BST yaitu Chief dan 1 orang ABK.

Pelatihan BST hanya dilakukan 1 kali pada tahun 2010 oleh Dinas Kelautan dan Perikanan (DKP) Bitung bekerjasama dengan Akademi Perikanan Bitung (APB) dan tidak semua awak kapal mendapatkan kesempatan mengikuti pelatihan tersebut. Kompetensi pekerja terhadap keselamatan kerja sering kali dinilai dari pengetahuan, pengertian serta penerapan peraturan dan prosedur keselamatan kerja, juga dari penerapan atas pelatihan keselamatan kerja yang diperoleh (Davies et al. 2001). Setiap kapten kapal soma pajeko sudah memenuhi syarat kompetensi kecakapan pelaut minimal SKK60 mil, namun tidak seluruh awak kapalnya mempunyai syarat kompetensi untuk bekerja di atas kapal dalam hal keselamatan di laut. Dengan demikian, kompetensi awak kapal soma pajeko masih belum merata dan hanya berdasar pada pengalaman turun temurun saja. Andi et al. (2005) menjelaskan bahwa pekerja dengan tingkat kompetensi yang baik diharapkan dapat meminimalisir terjadinya risiko kecelakaan kerja dan dapat membantu meningkatkan kompetensi pekerja yang lain terhadap keselamatan kerja.

Pembagian jabatan di atas kapal terdiri atas 4 (empat) perwira dengan tugas umum sebagai berikut:

1. Captain (Tonaas) : keputusan, proses penangkapan (fishing master).

2. Assistant captain : asisten fishing master.

3. Kepala kerja :menyiapkan kegiatan setting, hauling, dan penanganan hasil tangkapan.

4. Chief officer : administrasi suratsurat izin berlayar, pencatatan pembelian perbekalan, logistik, mengatur storage plan.

Pembagian jabatan telah sesuai dengan pengaturan organisasi di atas kapal pada umumnya. Hal ini menunjukkan telah ada pengaturan tanggungjawab sesuai dengan tugas-tugas perwira di tiap tahapan aktivitas pengoperasian soma pajeko di PPS Bitung.

\section{Tahapan aktivitas soma pajeko di Bitung}

Aktivitas dalam HTA dibagi menjadi beberapa level. Hal ini juga sangat bermanfaat untuk melihat aktivitas dalam berinteraksi dengan peralatan kerja dan aspek lingkungan kerja. Aktivitas dibagi atas beberapa level berdasarkan tujuan yang ingin dicapai (Lyons et al. 2004). Level 0 menunjukan aktivitas atau sub goals yang ingin dicapai. Dalam HTA juga dikenal plan yang menjelaskan mengenai urutan dan kondisi suatu aktivitas yang dilakukan. Selanjutnya, aktivitas ini dipecah menjadi operasi sampai level paling rendah (Lane et al. 2008). 


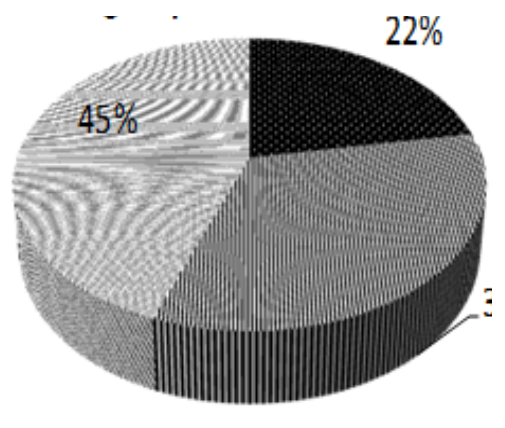

月SD II SMP

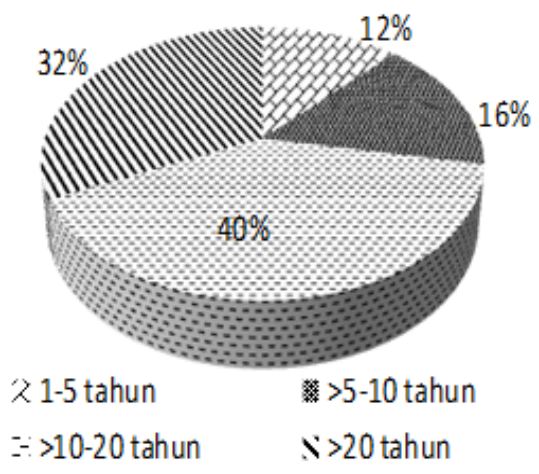

Gambar 3. Kondisi umum nelayan soma pajeko di PPS Bitung

Tahapan aktivitas soma pajeko di PPS Bitung dikelompokkan menjadi 8 tahapan aktivitas pokok, yaitu persiapan di darat, loading, trip to fishing ground, setting hauling, penanganan hasil tangkapan di atas kapal, trip to fishing base, dan unloading. Tiap tahapan akan dirinci lebih lanjut menjadi beberapa sub-aktivitas seperti ditunjukkan pada Tabel 2.

Pengoperasian alat tangkap soma pajeko yang dilakukan pada malam hari hingga pagi hari di perairan Bitung mempunyai potensi terjadinya kecelakaan bagi nelayan. Hal ini juga berlaku terhadap keselamatan nelayan pada aktivitas mulai dari persiapan di pelabuhan menuju lokasi fishing ground sampai kembali ke pelabuhan beserta muatan pada kapal.

Tabel 2. Hierarchical Task Analysis (HTA) pengoperasian soma pajeko

\begin{tabular}{|c|c|c|c|c|}
\hline No & Aktivitas & $\begin{array}{l}\text { Penanggung } \\
\text { jawab }\end{array}$ & $\begin{array}{l}\text { Intensitas } \\
\text { kerja (OA } \\
=\text { Orang } \\
\text { Aktivitas) } \\
\end{array}$ & $\begin{array}{l}\text { Jenis } \\
\text { aktivitas }\end{array}$ \\
\hline \multicolumn{5}{|c|}{ Tahap 1 (Persiapan) } \\
\hline 1 & $\begin{array}{l}\text { Pengurusan dokumen-dokumen SIB ( } 3 \\
\text { hari sekali) }\end{array}$ & Chief & 1 & Primer \\
\hline 2 & $\begin{array}{l}\text { Mendata ABK } \\
\text { - } \quad \text { Pengecekan kehadiran ABK } \\
\text { - Pembagian tugas ABK } \\
\text { Pembelian perbekalan crew kapal }\end{array}$ & Chief & $\begin{array}{l}1 \\
1 \\
1\end{array}$ & Primer \\
\hline 3 & Pengecekan dan perbaikan alat tangkap & Kepala kerja & 3 & Primer \\
\hline 4 & Pengecekan dan pengaturan mesin & Chief & 2 & Primer \\
\hline 5 & $\begin{array}{l}\text { Pengecekan kebutuhan blong dan ker- } \\
\text { anjang ikan }\end{array}$ & Chief & 3 & Primer \\
\hline \multicolumn{5}{|c|}{ Subtotal Tahap $1=12$ OA } \\
\hline \multicolumn{5}{|c|}{ Tahap 2 (Loading) } \\
\hline 1 & Pengangkutan dan pengisian bensin & Chief & 6 & Primer \\
\hline 2 & $\begin{array}{l}\text { Pengangkutan dan pengisisan es kedalam } \\
\text { palka }\end{array}$ & Chief & 6 & Primer \\
\hline
\end{tabular}




\begin{tabular}{|c|c|c|c|c|}
\hline No & Aktivitas & $\begin{array}{l}\text { Penanggung } \\
\text { jawab }\end{array}$ & $\begin{array}{c}\text { Intensitas } \\
\text { kerja (OA } \\
=\text { Orang } \\
\text { Aktivitas) }\end{array}$ & $\begin{array}{l}\text { Jenis } \\
\text { aktivitas }\end{array}$ \\
\hline 3 & Pengangkutan jerigen air minum & Chief & 6 & Primer \\
\hline 4 & $\begin{array}{l}\text { Pengangkutan blong dan keranjang } \\
\text { tambahan }\end{array}$ & Chief & 6 & Primer \\
\hline 5 & ABK naik ke kapal & Chief & 28 & Primer \\
\hline
\end{tabular}

Sub-total Tahap $2=52$ OA

Tahap 3 (Trip to Fishing Ground)

1 Bertolak dari dermaga

- Melepas tali tambat

- Juru mesin menyalakan motor dan

Kapten

Kapten mengarahkan kapal keluar kolam pelabuhan

- ABK mendorong kapal lain di sisi kanan dan kiri

2 Membuang air di lambung kapal

3 ABK memakan perbekalan

4 ABK mengganti pakaian/ mengenakan jas hujan

$5 \quad$ Persiapan alat tangkap

- Membuka terpal penutup jaring

- Menyiapkan jaring, pelampung dan cincin

6 ABK mematikan lampu di kapal

Kapten

Kepala kerja

2

Chief

Chief

Primer

Primer

2

7

Primer

Kepala kerja

Kepala kerja

8

Primer

6 Primer

Kepala kerja $\quad 1 \quad$ Primer

7 Tonaas mengarahkan kapal dengan

Kapten

2

Primer lampu sorot menuju FG

Sub-total Tahap $3=88$ OA

Tahap 4 (Setting)

12 ABK penyelam pengawas ikan turun di

Asisten

3

Primer dekat kapal lampu

Kapten

2 Pemasangan alat tangkap

- Menurunkan pelampung tanda

Kapten

4

Primer

- Mengatur bagian jaring untuk

Kepala kerja

11

Primer diturunkan

- Menurunkan bagian sayap jaring 1

- Menurunkan bagian badan jaring

- Menurunkan bagian sayap jaring 2

Kapten

Primer

Kapten

Primer

Kapten

Primer

3 Juru mudi menggerakkan kapal

Kapten

Primer melingkari kawanan ikan

4 Tonaas mengatur arah kapal dan

Kapten

7

7

7

2

2

Primer mengawasi bentuk jaring

5 ABK mempertahankan bentuk dan posisi Kepala kerja

Primer jaring

Sub-total Tahap $4=69$ OA 


\begin{tabular}{|c|c|c|c|c|}
\hline No & Aktivitas & $\begin{array}{l}\text { Penanggung } \\
\text { jawab }\end{array}$ & $\begin{array}{c}\text { Intensitas } \\
\text { kerja (OA } \\
=\text { Orang } \\
\text { Aktivitas) }\end{array}$ & $\begin{array}{l}\text { Jenis } \\
\text { aktivitas }\end{array}$ \\
\hline \multicolumn{5}{|c|}{ Tahap 5 (Hauling) } \\
\hline 1 & $\begin{array}{l}\text { Penyelam mengawasi ikan, jaring dan } \\
\text { memberikan kode }\end{array}$ & $\begin{array}{l}\text { Asisten } \\
\text { kapten }\end{array}$ & 3 & Primer \\
\hline 2 & Operator winch menyalakan mesin & Kapten & 2 & Primer \\
\hline 3 & ABK memasang tali kolor ke winch & Kapten & 5 & Primer \\
\hline 4 & $\begin{array}{l}\text { Operator mengoperasikan winch } \\
\text { menaikkan cincin-cincin }\end{array}$ & Kapten & 10 & Primer \\
\hline 5 & $\begin{array}{l}\text { Menjepitkan sebagian sayap } 1 \text { dan } 2 \text { di } \\
\text { bambu kapal (depan dan belakang) }\end{array}$ & Kepala kerja & 5 & Primer \\
\hline 6 & $\begin{array}{l}\text { ABK bersiap di posisi masing-masing } \\
\text { ( } 5-6 \text { haluan, } 15 \text { dek tengah, } 6-8 \text { buritan) }\end{array}$ & Kepala kerja & 28 & Primer \\
\hline 7 & $\begin{array}{l}\text { ABK menarik jaring dan menyalakan } \\
\text { lampu di dek }\end{array}$ & Kapten & 28 & Primer \\
\hline 8 & $\begin{array}{l}\text { Melepaskan ikan yang tersangkut pada } \\
\text { sayap dan/atau badan jaring }\end{array}$ & Chief & 28 & Primer \\
\hline 9 & $\begin{array}{l}\text { Juru mudi mengatur olah gerak kapal } \\
\text { saat hauling }\end{array}$ & Kapten & 2 & Primer \\
\hline 10 & $\begin{array}{l}\text { Mengatur posisi alat tangkap saat } \\
\text { hauling }\end{array}$ & Kapten & 28 & Primer \\
\hline \multicolumn{5}{|c|}{ Sub-total Tahap $5=139$ OA } \\
\hline \multicolumn{5}{|c|}{ Tahap 6 (Penanganan Hasil Tangkapan di atas Kapal) } \\
\hline 1 & $\begin{array}{l}\text { Mengangkat ikan dari kantong jaring } \\
\text { dengan alat serok }\end{array}$ & Kepala kerja & 16 & Primer \\
\hline 2 & $\begin{array}{l}\text { Memasukkan ikan ke dalam blong atau } \\
\text { palka bila blong penuh }\end{array}$ & Chief & 16 & Primer \\
\hline 3 & $\begin{array}{l}\text { Memecahkan es dan memasukkan ke } \\
\text { dalam blong }\end{array}$ & Kepala kerja & 6 & Primer \\
\hline 4 & $\begin{array}{l}\text { ABK merapihkan bentuk jaring untuk } \\
\text { setting selanjutnya }\end{array}$ & Kepala kerja & 28 & Primer \\
\hline 5 & $\begin{array}{l}\text { Bila tidak ada setting lanjutan maka } \\
\text { ikan disortir ke dalam keranjang }\end{array}$ & Kepala kerja & 11 & Sekunder \\
\hline \multicolumn{5}{|c|}{ Sub-total Tahap $6=77$ OA } \\
\hline \multicolumn{5}{|c|}{ Tahap 7 (Trip to Fishing Base) } \\
\hline 1 & Tonaas mengarahkan arah menuju FB & Kapten & 3 & Primer \\
\hline 2 & $\begin{array}{l}\text { Juru mudi mengatur kecepatan mesin } \\
\text { kapal }\end{array}$ & Kapten & 3 & Primer \\
\hline 3 & $\begin{array}{l}\text { ABK merapihkan bentuk jaring untuk } \\
\text { disimpan }\end{array}$ & Kepala kerja & 28 & Primer \\
\hline 4 & ABK menyortir ikan ke dalam keranjang & Chief & 11 & Primer \\
\hline 5 & ABK istirahat/memakan sisa perbekalan & Chief & 28 & Sekunder \\
\hline
\end{tabular}




\begin{tabular}{|c|c|c|c|c|}
\hline No & Aktivitas & $\begin{array}{l}\text { Penanggung } \\
\text { jawab }\end{array}$ & $\begin{array}{c}\text { Intensitas } \\
\text { kerja (OA } \\
=\text { Orang } \\
\text { Aktivitas) }\end{array}$ & $\begin{array}{l}\text { Jenis } \\
\text { aktivitas }\end{array}$ \\
\hline \multicolumn{5}{|c|}{ Tahap 8 (Unloading) } \\
\hline \multirow[t]{4}{*}{1} & $\begin{array}{l}\text { Melabuhkan kapal di kolam TPI } \\
\text { - ABK mendorong kapal di kanan dan } \\
\text { kiri kapal }\end{array}$ & Kapten & 7 & Primer \\
\hline & $\begin{array}{l}\text { - Juru mudi mengatur kapal untuk } \\
\text { berlabuh }\end{array}$ & Kapten & 2 & Primer \\
\hline & - Melemparkan tali & Kapten & 5 & Primer \\
\hline & - ABK menurunkan hasil tangkapan & Kapten & 7 & Primer \\
\hline 2 & $\begin{array}{l}\text { Keluar dari kolam pelabuhan menuju } \\
\text { dermaga soma pajeko }\end{array}$ & Kapten & 2 & Primer \\
\hline 3 & $\begin{array}{l}\text { ABK turun kapal dengan perlengkapan } \\
\text { masing-masing }\end{array}$ & Chief & 28 & Primer \\
\hline 4 & $\begin{array}{l}\text { Dua orang ABK Piket menjaga kapal dan } \\
\text { membersihkan kapal soma pajeko }\end{array}$ & Chief & 2 & Primer \\
\hline
\end{tabular}

Sub-total Tahap $8=53$ OA

\section{Porsi tanggung jawab perwira pada pengoperasian soma pajeko}

Hasil penelitian menunjukkan bahwa untuk pengoperasian soma pajeko teridentifikasi 8 aktivitas pokok dimana terdapat total 58 aktivitas. Setiap aktivitas yang melibatkan jumlah awak kapal, area kerja dan energi akan berisiko menimbulkan bahaya. Berdasarkan Tabel 2, dapat dihitung porsi beban tanggung jawab kerja dari tiap perwira soma pajeko. Porsi terbesar adalah Kapten sebanyak (40\%) dari total aktivitas pengoperasian soma pajeko (Gambar 4).

Saputra (2013) menyebutkan bahwa salah satu tanggung jawab nakhoda (kapten kapal) adalah membuat kapalnya layak laut agar tujuan keselamatan dan keamanan kapal, penumpang dan muatan terjamin. Oleh karena itu diperlukannya suatu kemampuan dan kecermatan seorang nakhoda dalam memimpin suatu kapal. Kapten kapal soma pajeko merangkap jabatan sebagai Tonaas atau Fishing Master yang menentukan keberhasilan atau tidaknya proses penangkapan ikan. Sesuai dengan tanggung jawabnya, jabatan kapten adalah pemimpin di atas kapal. Nelayan soma pajeko memiliki aturan "1 kapten, 1 kapal" yang artinya semua tanggung jawab atas keselamatan kapal saat berlayar, keselamatan awak, keselamatan alat tangkap yang dioperasikan.

Keterlibatan 4 perwira secara bersamaan terjadi pada tahap aktivitas ke-5 (hauling). Pada tahap hauling ini terlihat porsi tanggung jawab terbesar terletak pada kapten sebesar 60\%. Hal ini menjelaskan pula bahwa kapten mempunyai beban tanggung jawab penuh terhadap keberhasilan proses operasi penangkapan ikan.

Gambar 5 menunjukkan porsi beban tanggung jawab kerja dari 4 perwira soma pajeko di tiap tahapan kerja. Gambar tersebut menunjukkan bahwa keterlibatan 4 perwira secara bersamaan terjadi pada tahap aktivitas ke-5 (hauling). Tahap hauling menunjukkan porsi tanggung jawab terbesar terletak pada Kapten sebesar (60\%). Hal ini menjelaskan pula bahwa kapten mempunyai beban tanggung jawab terhadap keberhasilan proses operasi penangkapan ikan.

\section{Intensitas kerja nelayan soma pajeko}

Tabel 3 menunjukkan rincian banyaknya jumlah aktivitas pada pengoperasian soma pajeko. Aktivitas terbagi atas aktivitas primer dan sekunder. Aktivitas primer merupakan aktivitas yang harus dilakukan pada urutan tahapannya karena mempengaruhi keberhasilan proses untuk mencapai tujuan. Aktivitas sekunder tidak harus dilakukan sesuai urutannya karena bersifat optional.

Pengoperasian soma pajeko mempunyai 54 aktivitas primer dari total aktivitas sejumlah 58 aktivitas. Persentase aktivitas primer sebesar $93.10 \%$ dibandingkan aktivitas sekunder yang berjumlah 4 aktivitas (6.9\%). Tahapan aktivitas yang paling 
berisiko tinggi terhadap keselamatan kerja nelayan adalah tahapan ke-5 yaitu hauling. Pada tahapan ini semua aktivitas bersifat primer dan merupakan aktivitas yang paling tinggi melibatkan semua awak kapal (ABK dan perwira) di atas kapal.

Total Intensitas Kerja Primer (IKP) pada pengoperasian 1 (satu) unit soma pajeko adalah 468 OA dan total Intensitas Kerja Sekunder (IKS) adalah 95 OA. Intensitas Kerja Total (IKT) pada pengoperasian soma pajeko adalah 563 OA. Hal ini berarti bahwa untuk melakukan pengoperasian soma pajeko dari tahapan awal hingga akhir membutuhkan usaha kerja atau keterlibatan awak kapal setara dengan 563 orang. Indeks IKP dihitung pada tiap tahap aktivitas. Berdasarkan tabel yang disajikan ranking aktivitas paling tinggi adalah tahap ke-5 (hauling). Tahap aktivitas ke-5 (hauling) memiliki nilai indeks IKP yang terbesar yaitu sebesar 0.29. Tahapan ini mempunyai total 10 aktivitas $(17 \%$ dari $93.10 \%$ aktivitas primer) dan memiliki total intensitas kerja primer tertinggi yaitu sebanyak 139 OA dibanding aktivitas lainnya. Hal ini berarti bahwa untuk mencapai tujuan seluruh aktivitas tahap 5 (hauling) membutuhkan usaha keterlibatan awak kapal setara dengan 139 orang.

European Foundation for the Improvement of Living and Working Conditions (2001) menyatakan terdapat hubungan yang sangat kuat antara tingkat intensitas dengan masalah kesehatan di satu sisi, dan dengan akibat kecelakaan di sisi lainnya. Pekerja yang terpapar dengan intensitas tinggi juga lebih cenderung untuk melaporkan posisi yang melelahkan dan menyakitkan. Hal ini sesuai dengan pendapat Josephus (2011) bahwa purse seine (pukat cincin) merupakan alat penangkapan ikan dengan sistem kerja yang sangat mengandalkan keberadaan dan kekuatan fisik manusia sebab pada saat menarik, cincin dan jaring bertumpuh pada tali sehingga beban tarikan menjadi semakin berat, cepat lelah dan adanya keluhan muskuloskeletal. Keluhan tersebut apabila dibiarkan maka akan menimbulkan kecelakaan dan cidera akibat kerja. Berdasarkan hasil wawancara nelayan soma pajeko, hauling adalah aktivitas yang dirasakan paling berat dan beresiko tinggi terjadinya kecelakaan kerja. Pada tahap ini tetap membutuhkan tenaga manusia untuk menarik jaring walaupun terdapat teknologi winch untuk membantu menarik tali kolor dan cincin-cincin ke atas kapal. Hal ini menyebabkan awak kapal yang bekerja untuk pengoperasian soma pajeko diharuskan memiliki kekuatan fisik dan keterampilan yang memadai untuk kesuksesan terlaksananya aktivitas hauling. Intensitas kerja tinggi (high work intensity) merupakan keseluruhan kontribusi negatif terhadap kualitas pekerjaan intrinsik (pokok) yang mengacu pada intensitas usaha tenaga kerja selama waktu pekerjaannya (Eurofound 2012). Pengoperasian soma pajeko pada tahap setting dan hauling dapat dilakukan minimal 1-4 kali pengulangan. Pengulangan aktivitas tersebut membuat intensitas kerja awak kapal semakin tinggi dan menambah beban kerja bagi awak kapal. Hal ini akan berdampak pada kinerja awak kapal yang semakin menurun akibat kelelahan. Akibat dari kelelahan tersebut berpotensi untuk membuat peluang terjadinya kecelakaan kerja semakin besar yang dapat menimbulkan terjadinya kecelakan di laut karena kesalahan manusia. Tahap aktivitas hauling ini merupakan titik kritis (level aktivitas paling tinggi) dari tahapan keseluruhan pengoperasian soma pajeko yang mempengaruhi keselamatan kerja nelayan soma pajeko.

Khusus pada kegiatan perikanan, sebanyak $80 \%$ faktor kecelakaan laut disebabkan oleh kelalaian manusia (human erros). Penyebab utama kecelakaan dan hilangnya nyawa dalam industri perikanan tidak hanya dari buruknya rancangan, pembuatan, dan perlengkapan kapal, namun juga perilaku manusia yang tidak pantas, terkadang diperparah oleh kesalahan, keteledoran atau ketidaktahuan (FAO 2009). Pada tahapan hauling pengoperasian soma pajeko melibatkan seluruh awak kapal, membutuhkan intensitas kerja yang besar dimana beban tanggung jawab kerja terbesar terletak pada kapten/tonaas. Beban kapten sebagai pemimpin tertinggi di atas kapal sangat menentukan keberhasilan misi suatu pelayaran dan bertanggung jawab penuh terhadap keselamatan kerja nelayan dalam pengoperasian 1 unit penangkapan soma pajeko (mini purse seine) di Bitung.

Tahap 5 (hauling) merupakan subgoal dari pengoperasian soma pajeko yang memiliki potensi terjadinya risiko kecelakaan kerja terbesar terjadi dikarenakan intensitas kerja yang tinggi, sehingga tahap aktivitas ini merupakan titik kritis (level aktivitas paling tinggi) daritahapan keseluruhan pengoperasian soma pajeko yang mempengaruhi keselamatan kerja nelayan soma pajeko. Reason (2006) menegaskan bahwa kita tidak bisa mengubah kondisi manusia, namun kita 
bisa mengubah kondisi dimana manusia bekerja. Dua pendekatan untuk masalah manusia adalah pendekatan sistem dan manusia. Pendekatan manusia berfokus pada kesalahan individu, kesalahan mereka atas kelupaan, kurangnya perhatian, atau kelemahan moral. Pendekatan sistem berkonsentrasi pada kondisi dimana individu bekerja dan mencoba untuk membangun pertahanan untuk mencegah kesalahan atau mengurangi efeknya. Oleh karena itu perlu dilakukan suatu penelitian lebih lanjut untuk mengukur peluang resiko terjadinya kecelakaan akibat kesalahan manusia dengan pendekatan sistem keselamatan kerja nelayan pada pengoperasian soma pajeko.

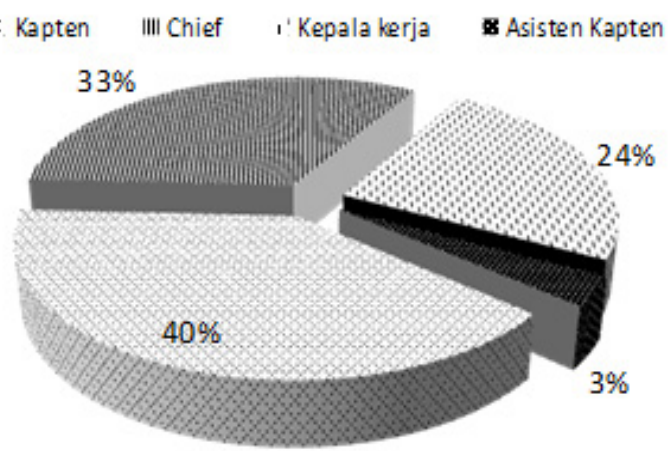

Gambar 4. Porsi beban tanggung jawab kerja 4 perwira

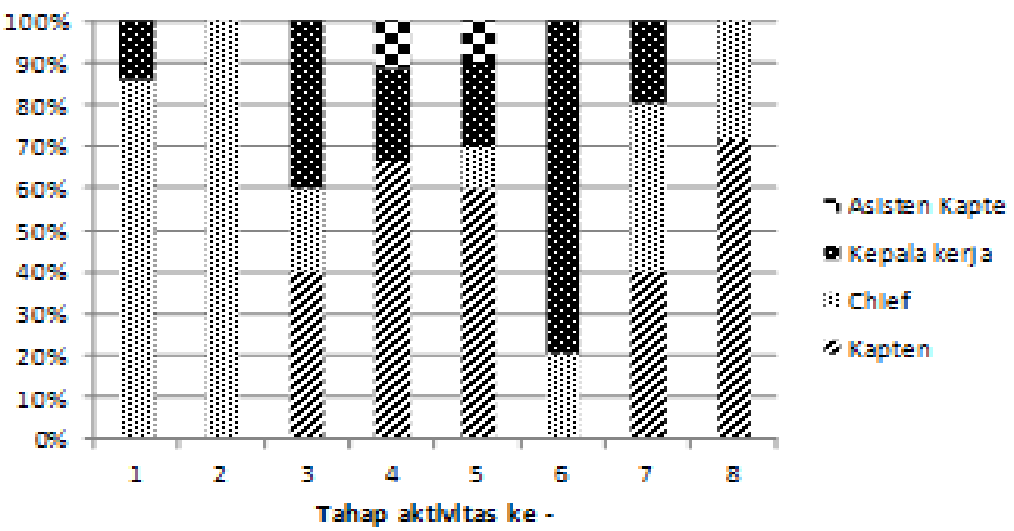

Gambar 5. Persentase tanggungjawab perwira di setiap tahap aktivitas soma pajeko

Tabel 3. Jumlah aktivitas primer dan sekunder pengoperasian soma pajeko

\begin{tabular}{cccc}
\hline \multirow{2}{*}{ Tahap ke- } & \multicolumn{2}{c}{$\sum$ aktivitas } & \multirow{2}{*}{ Total Aktivitas } \\
\cline { 2 - 3 } & Primer & Sekunder & 7 \\
2 & 7 & 0 & 5 \\
3 & 5 & 2 & 10 \\
4 & 8 & 0 & 9 \\
5 & 9 & 0 & 10 \\
6 & 10 & 1 & 5 \\
7 & 4 & 1 & 5 \\
8 & 4 & 0 & 7 \\
\hline Total & 7 & 4 & 58 \\
\hline
\end{tabular}


Tabel 4. Intensitas kerja awak kapal soma pajeko

\begin{tabular}{cccccc}
\hline Tahap ke-(i) & $\begin{array}{c}\text { IKPi } \\
\text { (OA) }\end{array}$ & $\begin{array}{c}\text { IKSi } \\
\text { (OA) }\end{array}$ & $\begin{array}{c}\text { IKTi } \\
\text { (OA) }\end{array}$ & Indeks IKPi & Rangking \\
\hline 1 & 12 & 0 & 12 & 0.026 & 8 \\
2 & 52 & 0 & 52 & 0.111 & 5 \\
3 & 32 & 56 & 88 & 0.068 & 7 \\
4 & 69 & 0 & 69 & 0.147 & 2 \\
5 & 139 & 0 & 139 & 0.297 & 1 \\
6 & 66 & 11 & 77 & 0.141 & 3 \\
7 & 45 & 28 & 73 & 0.096 & 6 \\
8 & 53 & 0 & 53 & 0.113 & 4 \\
\hline Total & 468 & 95 & 563 & & \\
\hline
\end{tabular}

\section{KESIMPULAN DAN SARAN}

\section{Kesimpulan}

Berdasarkan analisis yang telah dilakukan dari penelitian ini, maka dapat disimpulkan bahwa tahapan aktivitas soma pajeko di PPS Bitung diurutkan menjadi 8 tahapan aktivitas pokok. Terdapat 58 aktivitas yang harus dilakukan untuk mengoperasikan soma pajeko dari tahap awal hingga akhir. Intensitas kerja sebesar 563 OA dibutuhkan untuk melakukan pengoperasian soma pajeko dari tahapan awal hingga akhir, intensitas Kerja Primer (IKP) yang paling besar terjadi pada tahapan ke-5 (hauling) yang menunjukkan level aktivitas paling tinggi dengan Indeks IKP sebesar 0.29 dari keseluruhan aktivitas pengoperasian soma pajeko. Keterlibatan awak kapal pada tahap hauling adalah yang tertinggi dengan nilai intensitas kerja sebesar 139 OA sehingga memiliki potensi terjadinya risiko kecelakaan kerja yang lebih tinggi dibandingkan aktivitas lainnya.

\section{Saran}

Perlu dilakukan penelitian lebih lanjut untuk mengukur peluang resiko terjadinya kecelakaan akibat kesalahan manusia dengan pendekatan sistem keselamatan kerja nelayan pada aktivitas pengoperasian soma pajeko di Bitung.

\section{DAFTAR PUSTAKA}

Andi, Alifen RS, Chandra A. 2005. Model persamaan struktural pengaruh budaya keselamatan kerja pada perilaku pekerja di proyek konstruksi. Jurnal Teknik Sipil Untar. 12(3):127136.

Davies F, Spencer R, Dooley K. 2001. Summary guide to safety climate tool. Oxford: HSE.

Eurofound. 2012. Trends in job quality in Europe. Dublin: Luxembourg.

European Foundation for the improvement of living and working conditions.
2001. $3^{\text {rd }}$ European Survey. Dublin: Luxembourg.

[FAO] Food Agriculture Organization. 2010. Safety at sea for small-scale fisheries in developing countries. Rome: Italy. FAO.

[FAO] Food Agriculture Organization. 2009. The state of world fisheries and aquaculture. Rome: Italy. FAO.

Hamilton CT. 2007. 'Work Intensity' and the life course perspective: negotiating boundaries between work and life. Proceeding of Critical Management Studies. 11 - 13 July 2007. UK :University of Manchester

[ILO] International Labor Organization IN [FAO] Food Agriculture Organization. 2007. any other business. Outcome of SLF 50.STW 39/11/1. Sub Committee on Standard of Training and Watchkeeping. 39th Session. London.

[IMO] International Maritime Organization. 2007. Formal safety assessment. Consolidated text of the guidelines for formal safety assessment (FSA) for use in the IMO rule-making process. London.

Josephus J. 2011. Intervensi ergonomi pada proses penangkapan ikan dengan pukat cincin meningkatkan kinerja dan kesejahteraan nelayan di Amurang Kabupaten Minahasa Selatan Provinsi Sulawesi Utara [Disertasi]. Bali: Universitas Udayana.

Karman A. 2008. Pengembangan perikanan mini purse seine (soma Pajeko) berbasis rumpon di sekitar Pulau Mayau, Kota Ternate Provinsi Maluku Utara [Disertasi]. Bogor: Institut Pertanian Bogor.

Lane R, Stanton N, Harisson D. 2008. Hierarchical Task Analysis to medication administration errors. Kingston Lane Uxbridge: Departemen of Design and Information System Brunel University.

Lyons M, Adams S, Woloshynowych M, Vincent C. 2004. Human reliability analysis in healthcare: a review of technique. International Journal of 
Risk \& Safety in Medicine. 16:223-237. Purwangka F, Wisudo SH, Iskandar $\mathrm{BH}$, Haluan J. 2013. Kebijakan internasional mengenai keselamatan nelayan. Bulletin PSP. 21(1):51-65.

Reason J. 2006. Human error: models and management. BMJ 2000. 320:768770.

Saputra L, Adwani, Mahfud. 2013. Tanggung jawab nakhoda kapal cepat angkutan penyeberangan terhadap kelaiklautan kapal dalam keselamatan dan keamanan pelayaran. Jurnal Ilmu Hukum Pasca Sarjana Universitas Syiah Kuala. 2(2):19-28.

Silaban G. 2010. Hubungan antara jumlah kepesertaan tenaga kerja, jumlah kecelakaan kerja, dan jumlah jaminan kecelakaan kerja perusahaan kelompok jenis usaha III peserta program JKK pada PT Jamsostek Cabang Medan. Berita Kedokteran Masyarakat. 26(1):12-21.

Sugiyono. 2011. Metode Penelitian Kuantitatif, Kualitatif dan $r \& d$. Bandung: Alfabeta

Suwardjo D, Haluan J, Jaya I, Poernomo SH. 2010. Kajian tingkat kecelakaan fatal, pencegahan dan mitigasi kecelakaan kapal - kapal penangkap ikan yang berbasis operasi di PPP Tegalsari, PPN Pekalongan dan PPS Cilacap. Jurnal Teknologi Perikanan \& Kelautan.10 (1):61-72. 